\title{
UPTAKE OF FLUORESCENT-LABELED BSA INTO ROOT CELLS: ENDOCYTOSIS?
}

\author{
A. KAŹMIERCZAK and J. MASZEWSKI \\ Department of Cytophysiology - University of Łódź \\ 90-237 Łódź, ul. Pilarskiego 14, Poland
}

(Received: September 4, 1996. Accepted: May 26, 1997)

\begin{abstract}
Incorporation of rhodamine- and fluorescein-isothiocyanate labeled bovine serum albumin (BSA-TRITC, BSA-FITC) was examined in different root zones of the 3-day-old seedlings in Melandrium noctiflorum, Allium cepa and Zea mays. The uptake of fluorescent-labeled BSA was found: (1) species-specific, (2) cell-type dependent, and (3) cytochalasin B-sensitive. The characteristic punctute distribution of vesicles within the cytoplasm suggests the internalization of labeled proteins by endocytosis.
\end{abstract}

KEY WORDS: endocytosis, Melandrium noctiflorum L., Allium cepa L., Zea mays L., BSA, fluorescein isothiocyanate (FITC), tetramethylrhodamine isothiocyanate (TRITC), cytochalasin B.

\section{INTRODUCTION}

The uptake of macromolecules and particulate substances into a cell by an invagination of the plasma membrane and their internalization in a membrane-bound vesicles, referred to as endocytosis, is a well-known and widely-spread phenomenon among animals (reviewed by Goldstein et al., 1985; Rodman et al., 1990; Smythe and Warren 1991). The most important functions connected with this process seem to include: (I) the uptake of needed nutrients (e.g. vitamins) into the cell (Anderson et al., 1992), (II) the remodeling or repair of the cell membrane (Snider and Rogers, 1985), (III) the removal of signaling ligands (e.g. hormones, elicitors) from the cell surface following signal transduction (Carpenter and Cohen, 1979), (IV) the transport of molecules across an ephithelial cell (trancytosis; Mostov and Smister, 1985), (V) the delivery of active signaling components from the plasma membrane to internal organelles (Burwen and Jones, 1987), and (VI) the return of plasma membrane to the cell interior following secretory activity (Steinman et al., 1983).

The endocytic uptake usually begins at specialized regions termed clathrin-coated pits where the plasma membrane pinches off to form a closed clathrin-coated vesicle within the cytoplasm. Although the cage forms spontaneously at the cell surface, disassembly of coat immediately following endocytosis and release of the uncoated vesicle from the membrane is the energy-consuming process requiring an uncoating ATPase (Rothman and Schmid, 1986).

Until recently, endocytosis was cosidered impossible in plants because of constraints imposed by high turgor pressure pushing outward on the walls that surround the cell (Gradmann and Robinson, 1989; see also Low and Chandra, 1994). A further argument against endocytosis in plants, and one which develops from the first, is based on the assumption that the uptake of extracellular solutes would still enlarge internal hydrostatic pressure, because active mechanisms for dissipating the turgor are lacking (Cram, 1980). More recent experiments and estimations of the energetic expences (eg. Raven 1987; Saxton and Breidenbach, 1988) resulted, however, in different conclusions. A strong argument for endocytosis in higher plants comes from observations that the major components and structures that conduct endocytosis in animals are abundant in plants. Plant cells contain plasma membrane receptors, coated pits, coated vesicles, early and late endosomes, the Golgi apparatus, and a degradative compartment analogous to lysosomes (i.e. vacuoles; Low and Chandra, 1994).

Secondly, evidence is accumulating that macromolecular ligands (e.g. lectins, elicitors and vitamin-conjugated proteins) and impermeable solutes (e.g. heavy metals, ferritin), known to enter animal cells only by endocytosis, can also rapidly enter whole plant cells and structurally intact protoplasts (for references see Low and Chandra, 1994; comp. also "Discussion" to the present paper).

The third and more general reason emerges simply from the fact that there is a direct correlation between high secretory activity and elevated rates of endocytic uptake of solutes (Samuels and Bisalputra, 1990). Based upon this observation, endocytosis is believed to balance increased export during cell wall secretion. Hence, its role is directly connected with the requirement to compensate exocytosis in establishing a stable or moderately increasing plasma membrane surface area.

So far, experiments using tracer molecules such as cationised ferritin (Joachim and Robinson, 1984; Tanchak et al., 1984), heavy metals salt solutions (Hübner et al., 1985), and gold conjugated lectins (Hillmer et al., 1986) have allowed for the construction of a preliminary "trafficking map" including the endocytotic pathway and its acceptor compartments (Satiat-Jeunemaitre and Hawes, 1993). Although the routes may vary among different cellular systems, the current view comprises of clathrin-coated vesicles, the partially coated reti- 
culum (PCR), multivesicular bodies (MVBs), the trans-Golgi network and vacuoles.

In spite of the fact that all these strands of evidence support the concept of endocytosis in higher plants, a reliable and convenient probe of fluid phase endocytosis in intact plant cells is still lacking. Moreover, in receptor-mediated endocytosis, the first stable interaction following penetration of the ligand through the cell is its association with the plasma membrane receptor. Unfortunatelly, no receptor has been isolated or characterized from the plasma membrane of higher plants, except the auxin-binding protein from soybean and maize (Barbier-Brygoo et al., 1989; Hesse et al., 1989; Hicks et al., 1989). Apart from the membrane-bounded components and the clathrin-coated vesicles, the various elements of the endocytic pathway have yet to be isolated, purified and characterized at the biochemical level. Consequently, the study of endocytosis in plants is in its infancy.

The present investigation demonstrates that conjugates of bovine serum albumin (BSA) with both tetramethylrhodamine isothiocyanate (TRITC) and fluorescein isothiocyanate (FITC) can readily enter roots of Melandrium noctiflorum L., and to a lesser degree, of Allium cepa L. and Zea mays L. Experiments performed with the use of cytochalasin B (CB) suggest that the uptake of fluorescent markers is mediated by an actin-dependent mechanism, connected probably with the cortical layer of the cytoplasm.

\section{MATERIALS AND METHODS}

Seeds of Melandrium noctiflorum L. from wild-growing populations around the Łódź-district (central Poland), Allium cepa L. var. Wolska and Zea mays L. (both from Centrala Nasienna - Wrocław) were dark-germinated at $23{ }^{\circ} \mathrm{C}$ in Petri dishes on blotting paper moistened with distilled water.

\section{Protein labeling}

$2 \mathrm{mg}$ of bovine serum albumin (BSA; Sigma) was dissol-

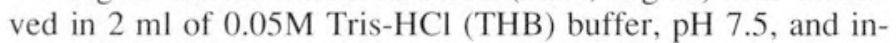
cubated with $10 \mu \mathrm{g}$ of tetramethylrhodamine isothiocyanate (TRITC, Sigma; in dimethylsulfoxide; DMSO). For FITC labeling, $2 \mathrm{mg}$ of BSA in THB was incubated with $20 \mu \mathrm{g}$ of fluorescein isothiocyanate (FITC, Sigma; 0.15M NaCl), pH 9.5 .

Both incubations were performed in the dark, at room temperature for 1 hour. Free dye was then removed by gel filtration on Sephadex G-50 (TRITC) or Sephadex G-25 (FITC) using $0.01 \mathrm{M}$ phosphate buffer, $\mathrm{pH}$ 7.6. The quantity of labeled protein was estimated according to Bradford (1976), and the amount of flurochrome was evaluated according to Brandtzaeg (1973).

\section{Incubations of roots with cytochalasin B and fluorochrome - labeled BSA}

Roots of 3-day-old seedlings were placed for 1, 5, 10 and $30 \mathrm{~min}$, and for 1, 7, 12 and 24 hours in aerated solutions of (I) BSA-TRITC $(70 \mu \mathrm{g} / \mathrm{ml}$ BSA), (II) BSA-FITC $(70 \mu \mathrm{g} / \mathrm{ml}$ BSA). Series III and IV were pretreated in a solution of 40 $\mathrm{mM} \mathrm{CB}$ for $30 \mathrm{~min}$ before incubation with a mixture composed of $80 \mathrm{mM} \mathrm{CB}$ and solution containing either (III) BSATRITC $(140 \mu \mathrm{g} / \mathrm{ml})$ or (IV) BSA-FITC $(140 \mu \mathrm{g} / \mathrm{ml}) ; 1: 1 \mathrm{v} / \mathrm{v}$.

Stock solution of cytochalasin B (CB; Sigma) was prepared by dissolving $1 \mathrm{mg}$ of the reagent in $60 \mu \mathrm{l}$ of ethanol. Subsequently, to obtain the required concentration, the stock solution was further diluted either with distilled water (for pre- treatment of roots before application of BSA-TRITC or BSAFITC conjugates) or with fluorochrome-labeled protein dissolved in water. Each time, the final concentration of $\mathrm{CB}$ was 40 $\mathrm{mM}$, which appeared to effectively arrest cytoplasmic streaming within the internodal cells of Chara (a CB testing system).

\section{Preparations and fluorescence microscopy}

Following incubations, seedlings were washed several times with distilled water and root tips (ca. $5 \mathrm{~mm}$ ) were cut off and gently squashed on slides under the coverslip. For fluorescence microscopy examinations 3 zones were chosen: (a) meristem, (b) elongation zone, and (c) differentiated zone. Observations were made using a Nikon epi-fluorescence system equipped with either excitation filters G-2A (TRITC) or B-2A (FITC), illuminating at $\gamma=510-560 \mathrm{~nm}$ and $\gamma=450-490 \mathrm{~nm}$, respectively. Microphotographs were made using Kodak Elite 400 film and excitation filter B-2A, which changed the orange emission of TRITC-fluorescing compartments to white, giving shorter exposition times during photographing. For each root zone, 30 cells were examined, and for each series the data were reproduced at least 3 times.

\section{Mitotic index}

Seedlings were fixed in cold Carnoy's mixture of absolute ethanol and glacial acetic acid $(3: 1)$ for $2 \mathrm{~h}$, washed with ethanol and rehydrated. Apical parts of roots were hydrolysed in $4 \mathrm{~N} \mathrm{HCl}$ for $1.5 \mathrm{~h}$ at $18{ }^{\circ} \mathrm{C}$, stained in Schiffs reagent (pararosaniline, Gurr) for $1 \mathrm{~h}$ at room temperature and soaked in $\mathrm{SO}_{2}$-water. After washing with distilled water, roots were gently squashed onto slides under glass coverslips, protected against drying with liquid rubber and the mitotic index (MI) was calculated, immediately. Mean values of MI were estimated using counts made from 5 seedlings and 2000 cells for each of the analysed root zones.

\section{RESULTS}

Preparations made of the squashed apical parts cut from the primary roots enabled longitudinal files of mature and maturing cells to be traced as they converge basipetally upon a region above the root cap (Fig. 1). The thick layer of cells compressed gently between the microscopic slide and the coverslip brought about difficulties of defining the meristematic zone, particularly in root apices of onion and maize; in Melandrium noctiflorum the meristem layers appeared much more distinct. The analysis of root organization has been complicated even further using the fluorescence microscopy. Hence, apart from the topological orientation, the criterion of cell dimensions (length to width ratio) was introduced to select each out of the 3 investigated root portions, i.e. (a) the meristem, (b) the elongation zone, and (c) the differentiation zone. Using the same technique of squashing, mitotic indices have been determined following the Feulgen-staining procedure (Table 1).

The sizes of meristematic cells differ considerably between the species. Due to mostly unidirectional root growth, the increase in cell volumes results mainly from the acropetal elongation. The longest zone composed of nearly isodiametric cells characterizes apical parts of roots in maize (about 1200 $\mu \mathrm{m}$ ), shorter in onion (about $700 \mu \mathrm{m}$ ), and the shortest in $M$. noctiflorum (about $400 \mu \mathrm{m}$ ). This, in turn, brings about species-specific variation in distances between the root tips and the elongation and differention zones which were taken into 

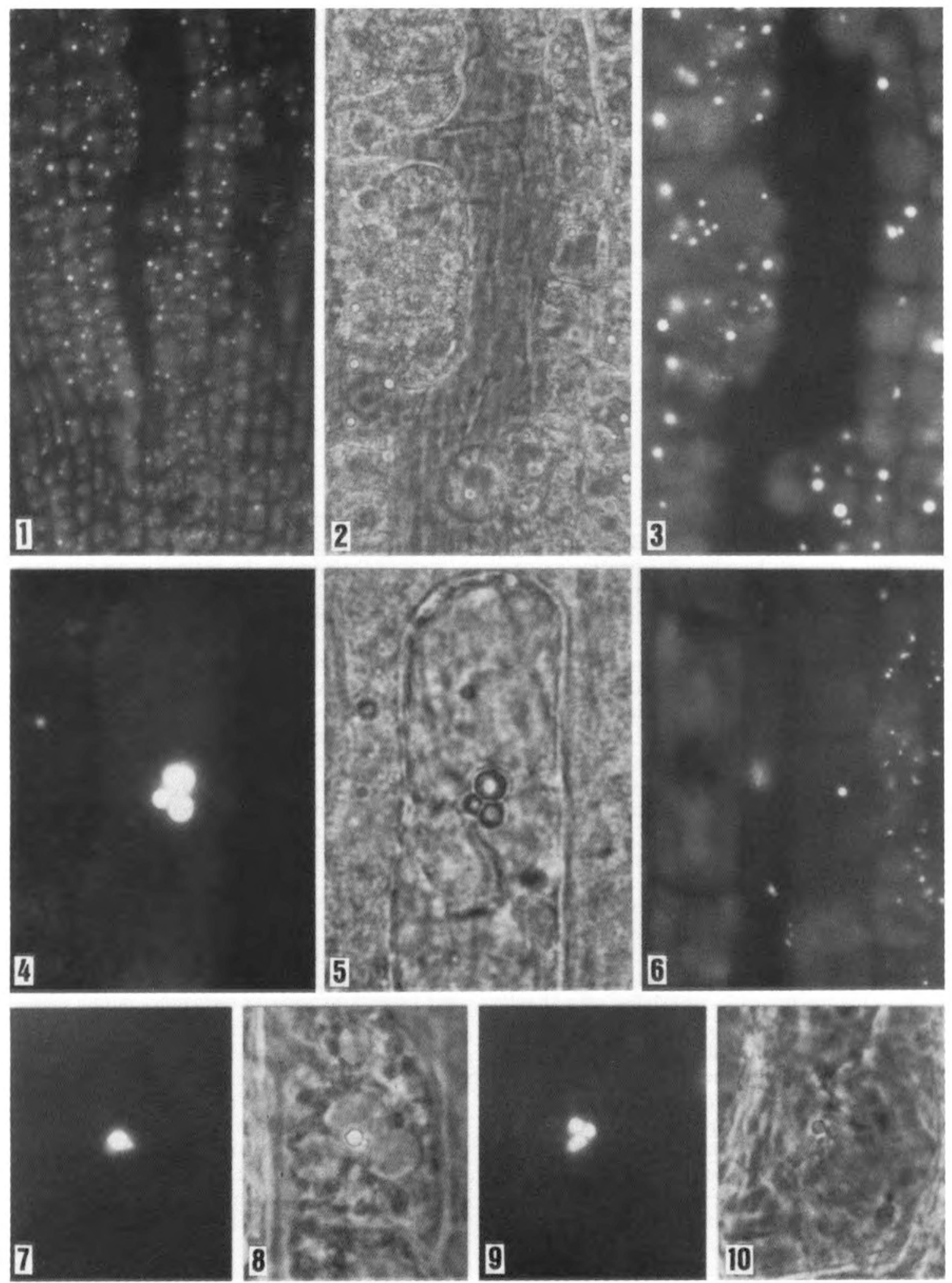

Fig. 1. Squashed root meristematic zone from Melandrium noctiflorum seedling. Fluorescence of vesicles filled with BSA-TRITC conjugates after $7 \mathrm{~h}$ incubation. X 200.

Figs 2-3. Magnified image of meristematic cells in Fig. 1, viewed using phase contrast (Fig. 2) and fluorescence microscopy (Fig. 3). Numerous compartments ranging from about 100 to $1500 \mathrm{~nm}$ in diameter, filled with BSA-TRITC. X 400.

Figs 4-5. Intracellular compartments filled with fluorescing BSA-TRITC conjugates in a differentiating cell of suprameristematic root zone from Melandrium noctiflorum seedling; $12 \mathrm{~h}$ incubation (Fig. 4). The same cell viewed using phase contrast microscopy (Fig. 5). Note that the large vacuole above the complex shows no traces of fluorescent labeling. X 1600.

Fig. 6. Parallel files of differentiating (right hand side) and meristematic (left hand side) cells in the transitory zone of a root from of Melandrium noctiflorum seedling; $12 \mathrm{~h}$ incubation. X 400.

Figs 7-8. A small vesicle filled with BSA-TRITC conjugates in the vicinity of the bigger compartment within the root meristematic cell of $M e$ landrium noctiflorum; $2 \mathrm{~h}$ incubation (Fig. 7). The same cell viewed using the phase contrast microscopy (Fig. 8). X 1600.

Figs 9-10. Complexes of compartments containing BSA-TRITC within a differentiating cell from Melandrium noctiflorum root; $2 \mathrm{~h}$ incubation (Fig. 9). The same cell viewed using phase contrast microscopy (Fig. 10). X 1600. 
TABLE 1. Mitotic index (MI; \%) in the control roots and numbers of endocytic vesicles per cell within analysed root zones of $M$. noctiflorum, A. cepa and Z. mays in the control (C) and cytochalasin B (CB) treated seedlings (12 h experiment)

\begin{tabular}{|c|c|c|c|c|}
\hline \multirow[t]{2}{*}{ Species } & & \multicolumn{3}{|c|}{ Root zones } \\
\hline & & meristematic & elongation & differentiation \\
\hline \multirow{3}{*}{ M. noctiflorum } & MI & 9.6 & 1.1 & 0 \\
\hline & $\mathrm{C}$ & $9.86 \pm 0.29$ & $6.86 \pm 0.41$ & $2.87 \pm 0.26$ \\
\hline & $\mathrm{CB}$ & $3.85 \pm 0.59$ & $2.34 \pm 0.22$ & $0.56 \pm 0.26$ \\
\hline \multirow{3}{*}{ A. сера } & MI & 6.3 & 0.6 & 0 \\
\hline & $\mathrm{C}$ & $6.43 \pm 0.27$ & $1.04 \pm 0.15$ & 0 \\
\hline & $\mathrm{CB}$ & $3.10 \pm 0.17$ & $0.35 \pm 0,02$ & 0 \\
\hline \multirow{3}{*}{ Z. mays } & MI & 7.4 & 0.4 & 0.1 \\
\hline & $\mathrm{C}$ & $0.94 \pm 0.02$ & 0 & 0 \\
\hline & $\mathrm{CB}$ & 0 & 0 & 0 \\
\hline
\end{tabular}

consideration during observations performed using the fluorescence microscopy after incubations with in BSA-TRITC or BSA-FITC conjugates. The cell lengths classified for quantitative analysis as representative for these two categories ranged from 3 to 4 times and from 5 to 6 times the average cellwidth, respectively.

Roots were exposed to fluorescent markers for varying time periods before washing in distilled water and examination. Each BSA-conjugate entered the meristematic cells of the root after $10 \mathrm{~min}$ incubation, yet the intensity of labeling increased significantly following treatment lasting up to at least 1 hour. The fluorescence images from the roots incubated with BSA-FITC bleached rapidly, making counting and photography difficult. The BSA-TRITC molecules appeared to be much more stable both in the course of experiments and during a long term storage.

The 7- and 24-hour incubations of primary roots from seedlings of each species with either BSA-FITC or BSA-TRITC conjugates gave broadly similar observations, regarding the mode of labeling. The most intense FITC- and TRITC-signaling was restricted to the meristematic zone lying several cell layers above the quiescent center (Fig. 2, 3). The labeling of cells was strictly confined to the small ball-shaped vacuoles ranging from a fraction of a micrometer to a maximum of about $3.8 \mu \mathrm{m}$ in diameter in $M$. noctiflorum, and to 2.0-2.5 $\mu \mathrm{m}$ in $A$. cepa and $Z$. mays. Fluorescing chain-like structures and aggregates composed of many small-sized vacuoles could be seen in some meristematic and supra-meristematic cells within the roots of $M$. noctiflorum (Fig. 4, 5 and Fig. 7-10). In the supra-meristematic elongating and differentiating zones, the vacuoles filled with BSA-FITC or BSA-TRITC maintained similar dimensions; concurrently, large centrally located vacuoles emerging in the course of cell elongation revealed no traces of increased fluorescence (Fig. 4, 5 and Fig. 7, 8). Within the roots of $Z$. mays seedlings, the uptake of labeled BSA conjugates was solely confined to the meristematic zone (Table 1).

Among the three examined species, the highest degree of BSA-TRITC uptake into root meristematic cells was found in M. noctiflorum (Fig. 3), while the lowest in Z. mays (Table 1). The rate of fluorescent probe uptake into the cells from elongation and differentiation zone decreases gradually (comp. Fig. 3, 4), and ceases completely 4 to $5 \mathrm{~mm}$ above the root apex within the highly differentiated zone. The total lengths of root apical fragments containing cells with fluores- cing vacuoles was found to vary from about $2.0 \mathrm{~mm}$ in $M$. noctiflorum to $2.5 \mathrm{~mm}$ in A. cepa, and $1.0 \mathrm{~mm}$ in Z. mays.

One of the aims of the present paper has been to study the action of cytochalasin B (CB) on BSA-TRITC uptake by the primary root cells of $M$. noctiflorum, A. cepa and Z. mays. In each case, the pre-treatment of seedlings with $40 \mathrm{mM} \mathrm{CB}$ prior to incubation in a CB-containing solution of fluorescently labeled BSA considerably reduced the number of fluorescing compartments within the cells of the meristematic zone (Table 1). Nearly proportional decreases have been revealed in elongating and differentiating root cells of $M$. noctiflorum, while in A. cepa and Z. mays, CB-induced inhibition of the probe uptake unabled the detection of any structuralized compartment filled with the fluorescent marker.

\section{DISCUSSION}

Due to size limitations placed by physical laws on structures recognized under any of the light microscopic systems, and because of inherent difficulties during preparation of root squashes, attempts to trace intracellularly the entire route of applied fluorescent markers would exceed far beyond the technical possibilities of a device used to perform our task. Howewer, the obtained results may suggest that both FITCand TRITC-labeled BSA molecules enter root cells and become internalized by fluid phase endocytosis (FPE). Despite the fact, that we cannot rule out release of free dye (FITC and/or TRITC, if any), in our opinion, there are at least three reasons qualifying such interpretation. Before listing and discussing the arguments, a more general remark should be made, concerning the character of BSA, as a probe.

Current knowledge about FPE pathways in plants has been built up mostly by experiments using heavy metal salts and impermeable fluorescent probes. Recent insights about how such low molecular compounds enter the cells resulted in opinions contesting many of the former conclusions, noting either the toxicity of applied markers (such as lanthanium, lead and uranium; Low and Chandra, 1994), or demonstrating that their internalization can often be carried out by more than one mechanism (Oparka, 1991). Thus, hoping to avoid possible impairment of other cellular functions, we have chosen FITC- and TRITC-labeled BSA. Despite relatively high molecular weight, silver enhanced BSA-gold complexes have been successfully used for visualization and quantitation of FPE in 
the studies performed on plant protoplasts (Villanueva et al., 1993). Evidence has been also presented from a number of investigations that cell wall porosity may permit slow penetration of macromolecules larger than $60 \mathrm{kDa}$ (e.g. Baron-Epel et al., 1988; Carpita et al., 1979; Gogarten, 1988; Horn et al., 1992; Tepfer and Taylor, 1981).

The data presented in Table 1, indicated that the endocytic uptake of fluorescent-labeled marker reveals a distinct species-specificity. Moreover, the diameters of fluorescent vesicles observed in $M$. noctiflorum and, to a lesser degree in $A$. cepa and Z. mays, suggest that most of the observed BSA-labeled compartments correspond with secondary areas of internalization, such as multivesicular bodies and small vacuoles, and do not represent nascent vesicles emerging at the cell surface. This conclusion agrees well with a great number of data pointing to plant multivesicular bodies (MVB) as a prominent category of stuctures engaged during endocytic transport of fluids. These 250-700 nm organelles containing multipe 50$100 \mathrm{~nm}$ vesicles are bounded by limiting membrane that may have plaques or regions of clathrin-like coat and coated pits (Samuels and Bisalputra, 1990; Tanchak and Fowke, 1987). Because incoming vesicles frequently are observed either attached or in proximity to multivesicular bodies, it is assumed that newly arrived vesicles are incorporated into MVB by fusion-invagination sequence (c.f. Low and Chandra, 1994; see also Fig. 7, 8, this paper).

Data reported in this study clearly indicate that in each of the three analysed species, the most intense fluorescence is confined to the meristematic zone of a root, containing cells characterized by a high mitotic and metabolic activity. This observation corresponds well with the general conviction that the insertion of exocytic vesicles into the plasma membrane during periods of intense secretory activity requires a route for return of membrane to intracellular compartments. From morphometric measurements of exocytic vesicle formation in secretion inhibited cells, it was calculated that higher plants must endocytose the equivalent of their entire plasma membranes within a period of $10 \mathrm{~min}$ to $3 \mathrm{~h}$, depending on the growth rate of the cell (c.f. Low and Chandra, 1994). Similarly, by measuring the increase in cell wall volume deposited during growth of root cells of Lobelia erinus, Samuels and Bisalputra (1990) estimated that to deliver the observed quantities of extracellular wall material, secretory vesicles totaling eigthfold more membrane area than the entire plasmalemma must fuse with the cell membrane. In this context, the data obtained from our experiments would imply that the cellgrowth cycles confined to meristematic zones require much more intense exchange of membranes than the processes correlated with cellular elongation and differentiation within the upper, supra-meristematic areas of the roots.

In further attempts to determine whether BSA-FITC/TRITC uptake is endocytic, we made use of cytochalasin B (CB) at a concentration effectively inhibiting cytoplasmic streaming within large internodal cells of Chara. Although, similar approach has been made in several experiments performed to characterize cellular internalization of oligodeoxynucleotides added to animal cells in culture (Loke et al., 1989; Yakubov et al., 1989; Neckers, 1993), to our best knowledge, no data has been yet reported concerning the plant cell systems. Considerable decrease in numbers of fluorescent vesicles per cell within each root segment strongly suggests that the transport of BSA-FITC and BSA-TRITC conjugates is largely dependent on unaffected functions pertained to actin filaments. Similar to what has been evidenced in mouse fibroblast L929 cells following application of sodium azide $(5 \mathrm{mM})$, deoxyglucose
(20 mM), or cytochalasin B (50 mg/ml; Yakubov et al., 1989; Neckers, 1993), pretreatment and incubation of seedling roots from both $M$. noctiflorum and $A$. cepa inhibited the uptake of fluorescent BSA markers by a comparable factor of 3 and 4 , respectively. Interestingly, within relatively short periods of incubations (both after 7 and 24 hours) in mixtures containing $\mathrm{CB}$ and BSA-TRITC conjugates, a small yet visible retardation of root growth has been observed, as compared with a BSA-TRITC series. This result seems to further support a role for endocytosis in membrane recycling necessary to fulfill requirements coupled with cellular proliferation.

\section{ACKNOWLEDGMENTS}

This work was supported by a grant from University of Łódź, No. 505/725

\section{LITERATURE CITED}

ANDERSON R.G.W., KAMEN B.A., ROTHBERG K.G., LACEY S.W., 1992. Potocytosis: sequestration and transport of small molecules by caveolae. Science $255: 410-411$.

BARBIER-BRYGOO H., EPHRITIKHINE G., KLAMBT D., GHISLAIN M., GUERN J., 1989. Functional evidence for an auxin receptor at the plasmalemma of tobacco mesophyll protoplasts. Proc. Natl. Acad. Sci. USA 86: 891-895.

BARON-EPEL O., GHARYAL P.K., SCHINDLER M., 1988. Pectins as mediators of wall porosity in soybean cells. Planta 175: 389-395.

BRADFORD M.M., 1976. A rapid and sensitive method for the quantitation of micro-gram quantities of protein utilizing the principle of protein-dye binding. Anal. Biochem. 72: 248-254.

BRANDTZAEG P., 1973. Conjugates of immunoglobulin $G$ with different fluorochromes. I. Characterization by anionic-exchange chromatography. Scand. J. Immunol. 2: 273-290.

BURWEN S.J., JONES A.L., 1987. The association of polypeptide hormones and growth factors with the nuclei of target cells. Trends Biochem. Sci. 12: 159-163.

CARPENTER G., COHEN S., 1979. Epidermal growth factor. Ann. Rev. Biochem. 48: 193-216.

CARPITA N., SABULARSE D., MONTEZINOS D., DELMER D.P., 1979. Determination of the pore site of cell walls of living plant cells. Science 205: 1144-1147.

CRAM W.J., 1980. Pinocytosis in plants. New Phytol. 84: 1-17.

GOGARTEN J.P., 1988. Physical properties of the cell wall of photoautotrofic suspension cells from Chenopodium rubrum L. Planta 174: 333-339.

GOLDSTEIN J.L., BROWN M.S., ANDERSON R.G.W., RUSSELL D.W., SCHNEIDER W.J., 1985. Receptor-mediated endocytosis: concepts emerging from the LDL receptor system. Annu. Rev. Cell Biol. 1: 1-39.

GRADMANN O., ROBINSON D.G., 1989. Does turgor prevent endocytosis in plant cells? Plant Cell Environ. 12: 151-154.

HESSE T., FELDWISCH J., BALSHUSEMANN D., BAUW G., PUYPE M., 1989. Molecular cloning and structural analysis of a gene from Zea mays (L.) coding for a putative receptor for the plant hormone auxin. EMBO J. 8: 2453-2462.

HICKS G.R., RAYLE D.L., JONES A.M., LOMAX T.L., 1989. Specific photo- affinity labelling of two plasma membrane polypeptides with an azido-auxin. Proc. Natl. Acad. Sci. USA 86: 4948-4952.

HILLMER S., DEPTA H., ROBINSON D.G., 1986. Confirmation of endocytosis in higher plant protoplasts using lectin-gold conjugates. Eur. J. Cell Biol. 41: 142-149.

HORN M.A., HENSTEIN P.F., LOW P.S., 1992. Characterization of parameters influencing receptor mediated endocytosis in cultured soybean cells. Plant Physiol. 98: 673-679.

HÜBNER R., DEPTA H., ROBINSON D.G., 1985. Endocytosis in maize root cap cells: Evidence using heavy metal salt solutions. Protoplasma 129: 214-222. 
JOACHIM S., ROBINSON D.G., 1984. Endocytosis of cationic ferritin by soybean leaf protoplasts. Eur. J. Cell Biol. 34: 212-216.

LOKE S.L., STEIN C.A., ZHANG X.H., MORI K., NAKANISHI M., SUBASINGHE C., COHEN J.S., NECKERS L.M., 1989. Characterization of oligonucleotide transport into living cells. Proc. Natl. Acad. Sci. USA 86: 3474-3478.

LOW P.S., CHANDRA S., 1994. Endocytosis in plants. Annu. Rev. Plant Physiol. Plant Mol. Biol. 45: 609-631.

MOSTOV K.E., SMISTER N.E., 1985. Transcytosis. Cell 43: 389-390.

NECKERS L.M., 1993. Cellular internalization of oligodeoxynucleotides. In: Antisense Research and Applications. CRC Press, pp. 451-460.

OPARKA K.J., 1991. Uptake and compartmentation of fluorescent probes by plant cells. J. Exp. Bot. 42: 565-579.

RAVEN J.A., 1987. The role of vacuoles. New Phytol. 196: 357-422.

RODMAN J.S., MERCER R.W., STAHL P.D., 1990. Endocytosis and transcytosis. Curr. Op. Cell Biol. 2: 664-672.

ROTHMAN J.E., SCHMID S.L., 1986. Enzymatic recycling of clathrin from coated vesicles. Cell 46: 5-9.

SAMUELS A.L., BISALPUTRA T., 1990. Endocytosis in elongating root cells of Lobelia erinus. J. Cell Sci. 97: 157-165.

SATIAT-JEUNEMAITRE B., HAWES C., 1993. Insights into the secretory pathway and vesicular transport in plant cells. Biol. Cell 79: 7-15.

SAXTON M.J., BREIDENBACH R.W., 1988. Receptor-mediated endocytosis in plants is energetically possible. Plant Physiol. 86: 993-995.

SMYTHE E., WARREN G., 1991. The mechanism of receptor-mediated endocytosis. Eur. J. Biochem. 202: 689-699.
SNIDER M.D., ROGERS O.C., 1985. Intracellular movement of cell surface receptors after endocytosis: resialylation of asialo-transferrin receptor in human erythroleukemia cells. J. Cell Biol. 100: 826-834.

STEINMAN R.M., MELLMAN I.S., MULLER W.A., COHN Z.A., 1983. Endocytosis and recycling of plasma-membrane. J. Cell Biol. 96: 1-27.

TANCHAK M.A., FOWKE L.C., 1987. The morphology of multivesicular bodies in soybean protoplasts and their role in endocytosis. Protoplasma 138: 173-182.

TANCHAK M.A., GRIFFING L.R., MERSEY B.G., FOWKE L.C., 1984. Endocytosis of cationised ferritin by coated vesicles of soybean protoplasts. Planta 162: 481-486.

TEPFER M., TAYLOR I.E.P., 1981. The permeability of plant cell walls as measured by gel filtration chromatography. Science 213: 761-763.

VILLANUEVA M.A., TAYLOR J., SUI X., GRIFFING L.R., 1993. Endocytosis in plant protoplasts: visualization and quantitation of fluid-phase endocytosis using silver-enhanced bovine serum albumin-gold. J. Exp. Bot. 44: 275-281.

YAKUBOV L.A., DEEVA E.A., ZARYTOVA V.F., IVANOVA E.M., RYTE A.S., YURCHENKO L.V., VLASOV V.V., 1978. Mechanism of oligonucleotide uptake by cells: Involvement of specific receptors? Proc. Natl. Acad. Sci. USA 86: 6454-6458.

\section{WNIKANIE BSA ZNAKOWANEGO FLUORESCENCYJNIE DO KOMÓREK KORZENIA: ENDOCYTOZA?}

\section{STRESZCZENIE}

Badano wnikanie albuminy surowiczej wołu znakowanej izotiocyjanianem rodaminy i fluresceiny (BSATRITC, BSA-FITC) do różnych stref korzeni 3-dniowych siewek Melandrium noctiflorum, Allium cepa and Zea mays. Wnikanie BSA znakowanego flurescencyjnie było: (1) gatunkowo specyficzne, (2) zależne od typu komórki, i (3) wrażliwe na cytochalazynę B. Charakterystyczne punktowe rozmieszczenie pęcherzyków wewnątrz cytoplazmy sugeruje, że znakowane białka docierają tam na drodze endocytozy.

SŁOWA KLUCZOWE: endocytoza, Melandrium noctiflorum L., Allium cepa L., Zea mays L., BSA, izotiocyjanian fluoresceiny (FITC), izotiocyjanian tetrametylorodaminy (TRITC), cytochalazyna B. 